\title{
Reduced levels of protein recoding by A-to-I RNA editing in Alzheimer's disease
}

\author{
KHEN KHERMESH, ${ }^{1}$ ANNA MARIA D'ERCHIA, ${ }^{2,3}$ MICHAL BARAK, ${ }^{1}$ ANITA ANNESE, ${ }^{2}$ CHAIM WACHTEL, ${ }^{1}$ \\ EREZ Y. LEVANON, ${ }^{1}$ ERNESTO PICARDI, ${ }^{2,3}$ and ELI EISENBERG ${ }^{4}$ \\ ${ }^{1}$ Mina and Everard Goodman Faculty of Life Sciences, Bar-Ilan University, Ramat-Gan 59002, Israel \\ ${ }^{2}$ Department of Biosciences, Biotechnology and Biopharmaceutics, University of Bari, Bari, 70126, Italy \\ ${ }^{3}$ Institute of Biomembranes and Bioenergetics, National Research Council, Bari, 70126, Italy \\ ${ }^{4}$ Sagol School of Neuroscience and Raymond and Beverly Sackler School of Physics and Astronomy, Tel Aviv University, Tel Aviv, 69978, Israel
}

\begin{abstract}
Adenosine to inosine (A-to-I) RNA editing, catalyzed by the ADAR enzyme family, acts on dsRNA structures within pre-mRNA molecules. Editing of the coding part of the mRNA may lead to recoding, amino acid substitution in the resulting protein, possibly modifying its biochemical and biophysical properties. Altered RNA editing patterns have been observed in various neurological pathologies. Here, we present a comprehensive study of recoding by RNA editing in Alzheimer's disease (AD), the most common cause of irreversible dementia. We have used a targeted resequencing approach supplemented by a microfluidic-based high-throughput PCR coupled with next-generation sequencing to accurately quantify A-to-I RNA editing levels in a preselected set of target sites, mostly located within the coding sequence of synaptic genes. Overall, editing levels decreased in AD patients' brain tissues, mainly in the hippocampus and to a lesser degree in the temporal and frontal lobes. Differential RNA editing levels were observed in 35 target sites within 22 genes. These results may shed light on a possible association between the neurodegenerative processes typical for AD and deficient RNA editing.
\end{abstract}

Keywords: Alzheimer disease; epigenetics; RNA editing; targeted resequencing

\section{INTRODUCTION}

It has been increasingly appreciated in recent years that epigenetic transcriptome diversity plays a major role in complex organisms. Alternative splicing, occurring in the vast majority of mammalian primary transcripts, is considered to be a key contributor to that diversity (Johnson et al. 2003; Sultan et al. 2008). An additional co/post-transcriptional process that appears to be widespread in mammals is RNA editing.

Of the various types of RNA editing, A-to-I base modification is the most common in higher eukaryotes (Bass 2002; Nishikura 2010; Savva et al. 2012; Li and Church 2013). It enzymatically deaminates individual adenosine (A) bases in the pre-mRNA to a modified base, inosine (I), which is recognized as guanosine $(\mathrm{G})$ by the cell translational apparatus. A-to-I RNA editing is catalyzed by the ADAR (adenosine deaminase acting on RNA) family of enzymes, acting mostly in a site-specific manner on dsRNA structures formed in the pre-mRNA molecules (Patterson and Samuel 1995; Melcher et al. 1996; Lehmann and Bass 2000). Three ADAR gene family members (ADAR1-3) have been identified in mammals.

Corresponding author: elieis@post.tau.ac.il

Article published online ahead of print. Article and publication date are at http://www.rnajournal.org/cgi/doi/10.1261/rna.054627.115. Freely available online through the RNA Open Access option.
ADAR (ADAR1) and ADARB1 (ADAR2) can be detected in many tissues, while ADARB2 (ADAR3) seems to be restricted to the brain (Jacobs et al. 2009; Horsch et al. 2011; Savva et al. 2012). It is believed that ADAR and ADARB1 are the main catalytic enzymes that are accountable for all A-to-I editing activity, while the third member, ADARB2 (ADAR3), lacks a catalytic domain and its function is yet unclear (Chen et al. 2000). ADAR has two distinct splice variants: the ADAR-p150 variant, transcribed from an IFNinducible promoter and detected mainly in the cytoplasm, and the constitutively expressed ADAR-p110 variant that is localized exclusively in the nucleus (Patterson and Samuel 1995).

Millions of genomic sites are targeted by ADARs in humans, but the vast majority resides in Alu repetitive elements within untranslated regions (Athanasiadis et al. 2004; Blow et al. 2004; Kim et al. 2004; Levanon et al. 2004; Barak et al. 2009; Bazak et al. 2014a). Many possible biological roles for A-to-I RNA editing in noncoding sequences has been discussed in the literature (Prasanth et al. 2005; Scadden 2005, 2007; Hundley et al. 2008; Chen and Carmichael 2009).

(C) 2016 Khermesh et al. This article, published in $R N A$, is available under a Creative Commons License (Attribution 4.0 International), as described at http://creativecommons.org/licenses/by/4.0/. 
However, naturally, much interest has been focused on the minute fraction of editing sites in protein coding genes that result in amino acid substitutions, also known as the recoding sites (Sommer et al. 1991; Niswender et al. 1999; Berg et al. 2001; Hoopengardner et al. 2003; Iwamoto and Kato 2003; Bhalla et al. 2004; Cenci et al. 2008; Schellekens et al. 2012). Recoding by A-to-I editing is a highly regulated process, whereas deregulated recoding has been associated with multiple ailments (Paz et al. 2007; Slotkin and Nishikura 2013; Tomaselli et al. 2014; Paz-Yaacov et al. 2015). Only a few dozen recoding sites are conserved across mammals, and hundreds of human-specific (or primate-specific) sites have been identified, mostly weakly edited ( $\mathrm{Li}$ et al. 2013; Pinto et al. 2014; Ramaswami and Li 2014).

Notably, many of the well-characterized recoding sites reside in brain-specific transcripts associated with neuronal functions. Several investigations have associated altered recoding levels in specific sites with various neurological and neurodegenerative disorders (Niswender et al. 2001; Vissel et al. 2001; Maas et al. 2006; Tariq and Jantsch 2012; Slotkin and Nishikura 2013; Gaisler-Salomon et al. 2014; Li et al. 2014), such as major depression, epilepsy, schizophrenia, amyotrophic lateral sclerosis, and Alzheimer's disease (Feldmeyer et al. 1999; Kortenbruck et al. 2001; Vollmar et al. 2004; Iwamoto et al. 2005, 2009). However, so far, only a small fraction of recoding sites has been characterized and investigated in a pathological context. Many studies have focused on the editing alteration of $\mathrm{Q} / \mathrm{R}$ site in GRIA2 gene of AMPA receptor, but for most sites close to nothing is known on the effect of recoding on the resulting proteins and the downstream effect on cell function (Kawahara et al. 2006; Kwak et al. 2008). Given the association between recoding and the nervous system, it is natural to explore altered recoding activity in specific brain pathologies across multiple recoding sites.

Alzheimer disease ([AD] OMIM \#104300) accounts for over $50 \%$ of all dementia cases, presently affecting more than 24 million people worldwide (Alzheimer Association 2014). It is characterized by a progressive decline in cognitive function, which typically begins with deterioration in memory. The neuropathological hallmarks of the $\mathrm{AD}$ brain comprise extracellular precipitations of the $\beta$-amyloid peptide, which is derived from the amyloid precursor protein (APP) by proteolytic cleavage, and the presence of neurofibrillary inclusions composed of an abnormally phosphorylated and aggregated microtubule-associated $\tau$ protein. As a consequence of neurofibrillary inclusions, $\mathrm{AD}$ is accompanied by the progressive loss of neurons and inflammation around the senile plaques with reactive accumulation of microglial cells. Nevertheless, the etiological mechanisms underlying the neuropathological changes in $\mathrm{AD}$ remain unclear (Serrano-Pozo et al. 2011). Neuroprotective strategies should be implemented prior to neuronal loss and degeneration.

However, this requires preclinical markers to identify susceptible patients and early pathogenic mechanisms to serve as therapeutic targets. Transcriptomic analyses, that assume no a priori etiological hypotheses, promise much in elucidating the pathogenesis of complex diseases like $\mathrm{AD}$ and providing novel bio-markers.

Here we study globally the recoding activity in $\mathrm{AD}$ patients, looking for aberrations in the corresponding editing profile. We have selected 118 RNA editing sites located in 72 genes, most of which are located in coding regions and lead to amino acid substitution. The selected target-set is enriched in sites that are conserved through mammalian evolution. We then utilized an advanced targeted resequencing system that is built around the Fluidigm Access-Array (Fl-AA) platform, for microfluidic-based amplification of selected target regions across a multi samples panel (mmPCR) followed by in-parallel next-generation sequencing, to compare the editing profile between normal and $\mathrm{AD}$ brain tissues (Zhang et al. 2014).

\section{RESULTS}

\section{Compiling the A-to-I editing sites target-set that is used in the targeted resequencing protocol}

In the first two decades of RNA editing study, the method of choice for editing detection was low throughput PCR-based saturated amplification of a single locus, followed by Sanger DNA sequencing. Analyzing sequencing chromatograms, one may detect and quantify editing levels in the given site, with a typical accuracy of $\sim 5 \%$ (Li et al. 2009; Picardi et al. 2012). Introduction of RNA-seq techniques has led to massive enrichment in newly discovered A-to-I editing sites (Bahn et al. 2012; Park et al. 2012; Peng et al. 2012; Ramaswami et al. 2012; Bazak et al. 2014a,b). However, RNA-seq is generally less accurate in quantifying RNA editing levels due to the moderate read coverage currently available (Ramaswami et al. 2013). Several attempts have been made to couple targeted amplification and next-generation sequencing for accurate quantification of RNA editing with limited success ( $\mathrm{Li}$ et al. 2009; Sanjana et al. 2012; Ramaswami et al. 2013). Very recently, a more robust experimental system which combines microfluidics-based multiplex PCR has been presented by Zhang et al. (2014). This innovative method comes with several benefits over previous approaches. Microfluidics enables the parallel analysis of multiple samples and target sites, while targeted deep sequencing provides sufficient per-base depth to allow reliable quantification for all sites studied.

Here, we apply for the first time this targeted resequencing strategy in order to investigate potential RNA editing alterations in specific brain regions obtained from $\mathrm{AD}$ brains. Since this methodology is PCR based, the first step of the experimental procedure was to carefully select a relevant subset of RNA editing targets. We searched the RADAR database (v.2), which stands as a comprehensive collection of rigorously annotated RNA editing sites, for editing sites residing 
out of Alu repeats (Ramaswami and Li 2014). The selected sites were then filtered according to the following five guiding principles: preference for sites (i) located within protein coding regions, (ii) resulting in nonsynonymous amino acid changes, (iii) exhibiting evolutionarily conserved editing in at least one of the three mammals: chimpanzee, rhesus, and mouse, (iv) located in genes associated with neuronal functions and plasticity, and (v) sites that previously had recorded levels of RNA editing. The final list of targeted sites included 118 sites that are located in 72 different genes (Supplemental Table S1). Of these, 98 sites are located in protein coding regions of 67 genes, nine sites are in the $3^{\prime}$-UTR of two genes and 11 sites reside in three noncoding RNA genes (lncRNAs). Overall, the selected target-set represented a comprehensive panel of RNA editing sites well-positioned to assess A-to-I editing recoding capacity.

Notably, our target-set included RNA editing positions located in membrane receptors and ion channels known to play relevant biological roles in maintaining the correct neuronal physiology and cellular homeostasis.

\section{Comprehensive and site-specific differential RNA editing levels detected in AD and NDC}

The microfluidics-based multiplex PCR (mmPCR) approach for targeted resequencing is built around the Fluidigm Access Array, which enables uniform amplification of 48 different PCR products from each of the 48 RNA samples in a single experiment (Zhang et al. 2014). One may put more than one primer set in each well, increasing the number of amplicons per experiment even further. Output PCR amplicons are labeled with barcode sequences specific for each sample by a subsequent PCR and finally pooled for deep sequencing in order to obtain high coverage that allows for an accurate measurement of A-to-I RNA editing levels per genomic locus. Here, we used this platform to measure editing levels of the selected target-set of human editing sites in multiple diseased $(\mathrm{AD})$ and in age- and sex-matched nondemented healthy controls (NDC) samples, originating from three brain regions: hippocampus $(\mathrm{HpC})$, temporal lobe (TL) and frontal lobe (FL). The specific brain regions were chosen because they are known to be affected along the progression of the disease (Ray and Zhang 2010; Serrano-Pozo et al. 2011). Indeed, $\mathrm{HpC}$ is one of the primary and major brain locations damaged by extracellular precipitations of the $\beta$-amyloid peptide, showing extended neurodegeneration. Gradually, pathological lesions advance devastating temporal and frontal areas of neocortex.

We assayed all 118 editing sites that were primarily targeted. Of these, we successfully amplified and identified by sequence alignment 115 targeted sites (113 in HpC samples, 108 in TL and 107 in FL; Supplemental Table S2). To allow for accurate quantification of editing levels, we discarded all measurements with read coverage $<500$ reads, and considered only sites for which at least five normal and five diseased samples (of a given brain tissue-type) passed this cutoff, resulting in 66 target sites that were further analyzed (Supplemental Table S2).

In $\mathrm{HpC}$, we found 21 differentially edited sites (Table 1; Fig. 1A), 20 of which are under edited in $\mathrm{AD}$ compared with NDC. The global editing signal, as measured by the mean editing level across all 66 sites was also reduced in $\mathrm{AD}(21.8 \% \pm 4.5 \%$ in $\mathrm{AD}, 26.8 \% \pm 3.5 \%$ in NDC, $P=0.03$, $t$-test). This result is at odds with the fact that the expression levels of all three ADAR variants (ADAR-p110, ADAR-p150 and ADARB1) are at least as high in AD as they are in NDC (Fig. 4). Similar results were found for TL and FL. In TL, 19 target sites showed significant differential editing levels (Table 2; Fig. 1B), 18 of which exhibiting under-editing in AD. In FL, only eight sites show statistically significant differential editing levels in AD compare with NDC (Table 3; Fig. $1 C)$, with all sites exhibiting hypo-editing in $\mathrm{AD}$. In addition, the global editing signal was reduced in $\mathrm{AD}$ in both brain regions: $22.5 \% \pm 4.8 \%$ in $\mathrm{AD}$ versus $24.4 \% \pm 4 \%$ in NDC for $\mathrm{TL}(P=0.002 ; t$-test $)$, and $23.5 \% \pm 4 \%$ in $\mathrm{AD}$ versus $27 \% \pm$ $2.6 \%$ in healthy controls (NDC) in FL $\left(P=7.0 \times 10^{-8} ; t\right.$ test). Interestingly, three hypo-edited sites (in the UNC80 and MEG3 genes) were consistently detected in all three tissues (Table 6).

Our target-set of RNA editing sites includes 32 positions for which the editing level is reported in the RADAR database (Ramaswami and Li 2014). We have verified (Supplemental Table S4) that the editing levels recorded for this group of sites correlate with those measured in our study (bearing in mind differences in the brain region of origin and their characteristics).

\section{Analysis of clustered RNA editing sites}

Several genes within our target-set harbor a number of editing sites located in close proximity. In these cases, the calculated percentage of $\mathrm{A} / \mathrm{G}$ does not fully reveal the actual impact editing may have on the resulting protein, because it does not provide information on all the possible combinations of editing events. The most prominent example for this phenomenon is the serotonin receptor HTR2C, a member of the large family of seven transmembrane receptors. It harbors five editing sites known as A, B, C' (previously called E), C and D all residing within 14 bp span of exon 5, corresponding to the second intracellular loop, a region important for G-protein coupling (Burns et al. 1997; Wang et al. 2000; Kawahara et al. 2008). These sites are predicted to occur within amino acid positions 157, 159 and 161. The recoding of these DNA nucleotides by A-to-I RNA editing at these sites, generates up to 32 different mRNA variants that encode for up to 24 different protein isoforms, with varying biochemical properties. The fully edited receptor isoform (corresponding to the amino acids VGV) was shown to have a large reduction of agonist-stimulated G-protein coupling compared with the unedited receptor isoform (corresponding to the amino acids 
TABLE 1. Target sites with significant differential editing levels in hippocampus of AD and NDC

\begin{tabular}{|c|c|c|c|c|c|c|c|}
\hline Gene name & Edit site location & $\begin{array}{l}\text { Edit \% } \\
\text { HpC-HC }\end{array}$ & $\begin{array}{l}\text { STEDV, } \\
\text { HpC-HC }\end{array}$ & $\begin{array}{l}\text { Edit \% } \\
\text { HpC-AD }\end{array}$ & $\begin{array}{l}\text { STEDV, } \\
\text { HpC-AD }\end{array}$ & $\begin{array}{c}\text { Edit \% difference } \\
\text { (HC-AD) }\end{array}$ & $P$-value \\
\hline CACNA1D & chr3:53820892 & 14.178 & 8.153 & 8.673 & 7.210 & 5.505 & 0.023 \\
\hline COPA & chr1:160302244 & 25.574 & 7.059 & 35.627 & 13.921 & -10.053 & 0.003 \\
\hline DDX58 & chr9:32456368 & 18.475 & 7.288 & 11.548 & 9.655 & 6.927 & 0.015 \\
\hline DDX58 & chr9:32456365 & 29.485 & 11.187 & 20.050 & 14.331 & 9.435 & 0.025 \\
\hline DDX58 & chr9:32456371 & 21.610 & 9.260 & 14.601 & 10.612 & 7.010 & 0.030 \\
\hline FBXL6 & chr8:145579192 & 28.044 & 10.851 & 17.202 & 13.518 & 10.841 & 0.008 \\
\hline FIS1 & chr7:100887329 & 10.309 & 2.696 & 7.849 & 4.653 & 2.459 & 0.030 \\
\hline FLJ43663 & chr7:130629626 & 33.958 & 13.876 & 19.480 & 13.073 & 14.478 & 0.001 \\
\hline FLJ43663 & chr7:130629625 & 26.780 & 12.618 & 14.795 & 10.507 & 11.986 & 0.001 \\
\hline FLJ43663 & chr7:130629624 & 53.764 & 14.294 & 39.654 & 24.410 & 14.111 & 0.019 \\
\hline GRIA3 & chrX:122598962 & 60.356 & 17.679 & 45.818 & 21.510 & 14.538 & 0.024 \\
\hline GRIA4 & chr11:105804694 & 39.721 & 14.282 & 27.197 & 22.048 & 12.525 & 0.046 \\
\hline GRIK1 & chr21:30953750 & 50.246 & 10.210 & 42.179 & 14.295 & 8.067 & 0.055 \\
\hline IGFBP7 & chr4:57976234 & 33.373 & 12.304 & 22.435 & 17.020 & 10.939 & 0.026 \\
\hline KCNA1 & chr12:5021742 & 9.167 & 7.255 & 4.701 & 5.403 & 4.465 & 0.023 \\
\hline MEG3 & chr14:101312645 & 10.016 & 2.989 & 6.252 & 3.220 & 3.764 & 0.000 \\
\hline MEG3 & chr14:101312647 & 58.606 & 13.152 & 37.548 & 20.794 & 21.058 & 0.001 \\
\hline NARF & chr17:80441043 & 45.141 & 14.457 & 29.094 & 28.299 & 16.047 & 0.025 \\
\hline NOVA1 & chr14:26917530 & 8.729 & 6.840 & 3.775 & 3.760 & 4.954 & 0.012 \\
\hline PTPN14 & chr1:214529740 & 40.742 & 17.699 & 28.121 & 20.282 & 12.622 & 0.040 \\
\hline UNC80 & chr2:210835613 & 4.882 & 4.902 & 2.080 & 1.962 & 2.801 & 0.037 \\
\hline
\end{tabular}

INI) (Berg et al. 2001). The RNA editing levels recorded for each of the four prominent sites A, B, C and D separately did not exhibit a statistically significant reduction in each of the three brain regions studied. However, we noticed that all sites were less edited in $\mathrm{AD}$ (Table 4; Fig. 2), suggesting a possible synergetic effect on the distribution of protein variants. Therefore, we analyzed the abundance of each of the 32 transcript variants, and found a statistically significant increase in the level of the un-edited form encoding for INI isoform in $\mathrm{AD}$ samples compare with NDC in the $\mathrm{HpCpCH}$. This was accompanied by a $13 \%$ decrease in the level of the fully edited VGV version and the partially edited VDV version (Table 5; Fig. 3A-C). These results highlight the importance of studying correlations between neighboring recoding sites, which were by and large overlooked in the past (Barak et al. 2009; Morabito et al. 2010).

\section{Relative mRNA expression of ADAR1 and ADARB1 show a complex pattern of regulation in NDC and AD samples}

Real-time quantitative RT-PCR was performed to calculate the normalized differences in ADAR mRNA levels between hippocampus, frontal and temporal lobes samples of $\mathrm{AD}$ to controls. Results are shown in Figure 4A-C. Results show a significant overexpression of hADAR-p150 endogenous transcripts levels in hippocampus $(\mathrm{HpC})$ of $\mathrm{AD}$ only, which to some extent is indicative of the neuro-inflammatory processes typical to AD (Fig. 4B). The hADARB1 exhibits an overexpression in AD compare with NDC in the temporal lobe only
(Fig. 4C). Lastly, hADAR-p110 isoform shows down-regulation of endogenous transcription levels in $\mathrm{AD}$ compare with NDC in the temporal lobe, while displaying an opposite trend of overexpression in the frontal lobe (Fig. 4A). We note that although the global editing levels (mainly reflecting $A l u$ editing activity) correlate well with ADAR expression levels, recoding levels present a more complex picture, with no simple correlation to ADAR levels (Maas et al. 2001; Jacobs et al. 2009; Wahlstedt et al. 2009; Garncarz et al. 2013).

\section{DISCUSSION}

Recent massive expansion of transcriptome-wide data allowed for uncovering millions of novel A-to-I RNA editing sites, the vast majority of these reside within repeated sequences and introns (Park et al. 2012; Peng et al. 2012; Ramaswami et al. 2012, 2013; Bazak et al. 2014a). Yet, recoding sites continue to be the focus of most interest, especially as functional impact of RNA editing is discussed. While RNA-seq data present many opportunities in terms of editing detection, it performs rather poorly in quantification, as reads coverage is still not high enough for accurate measurement of the editing level. In cases (such as the one presented here) where the difference between healthy and diseased samples is rather small in terms of editing level, one must resort to alternative methods. Moreover, RNA-seq of hundreds of samples is still rather expensive, and the financial limitation hinders the study of many important conditions. We used an innovative targeted resequencing approach, developed to address these issues, which combines the robustness 

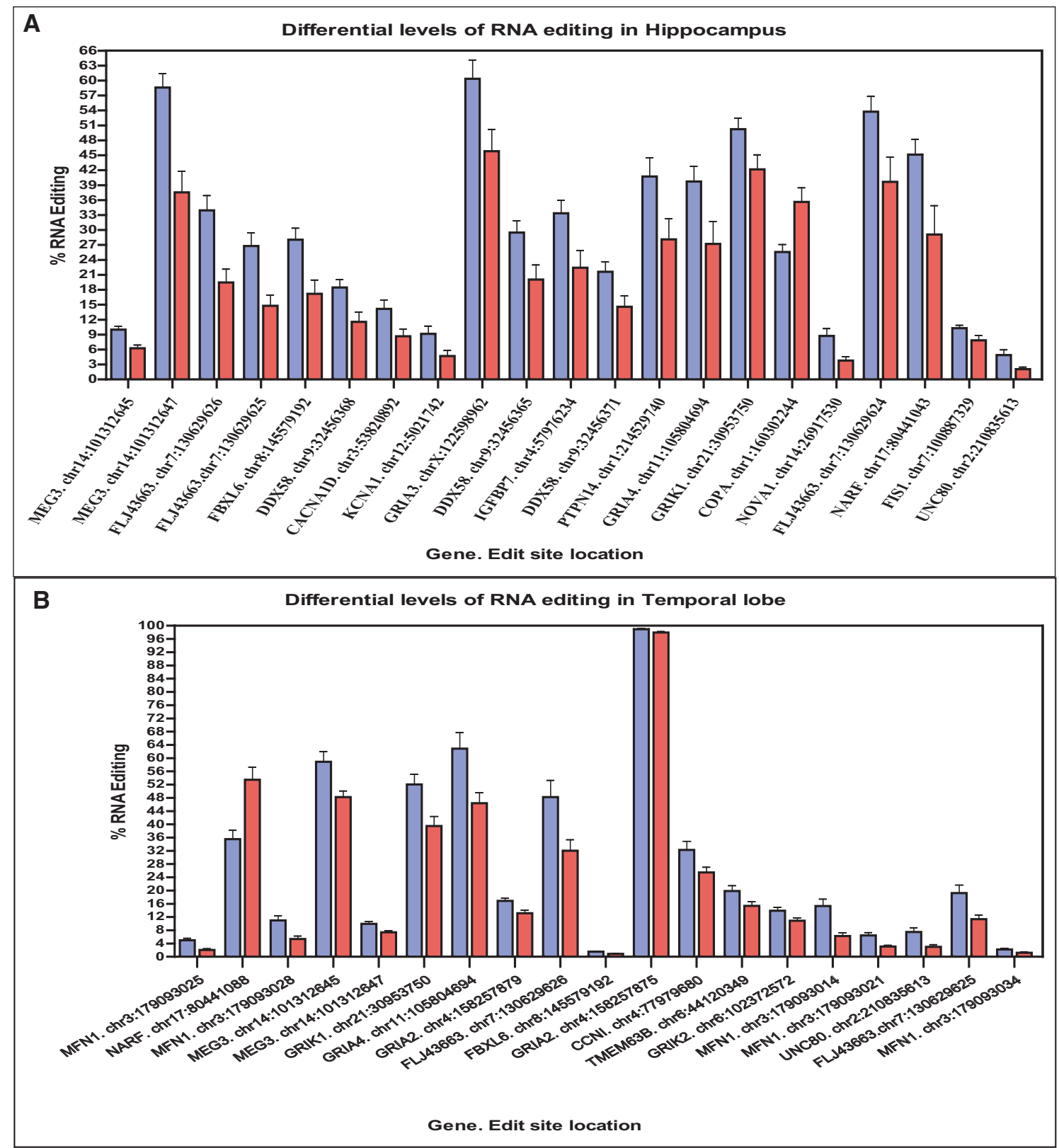

C

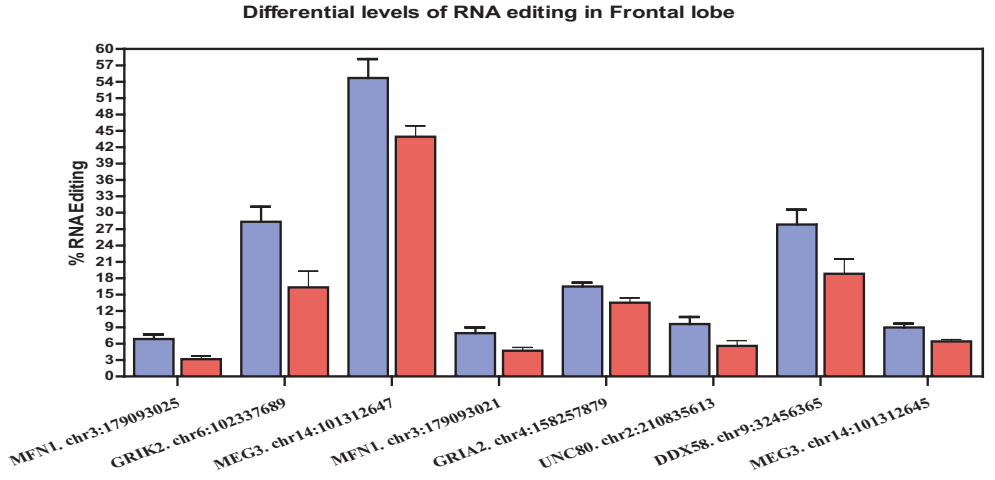

Gene. Edit site location

FIGURE 1. RNA editing target sites that show significant differential levels of NDC and AD. (A) In Hippocampus, 21 editing target sites exhibiting differential levels of A-to-I RNA editing were detected in $\mathrm{AD}$ (red bars) and in NDC (blue bars). Twenty sites show hypo-editing in AD and one site (COPA. Chr1:160302244) shows hyper-editing ( $n=28$ for AD, $n=20$ in NDC). (B) In temporal lobe, 19 editing target sites exhibiting differential levels of A-to-I RNA editing were detected in AD (red bars) and NDC (blue bars). Eighteen sites show hypo-editing in AD and one site (NARF. Chr17:80441088) showing hyper-editing ( $n=13$ for $\mathrm{AD}, n=11$ in NDC). (C) In frontal lobe, eight editing sites detected in $\mathrm{AD}$ (red bars) and $\mathrm{NDC}$ (blue bars). All sites show hypo-editing in $\mathrm{AD}(n=13$ for $\mathrm{AD}, n=11$ in NDC). All values represented as mean $+\mathrm{SEM}$. 
TABLE 2. Target sites with significant differential editing levels in temporal lobe of AD and NDC

\begin{tabular}{|c|c|c|c|c|c|c|c|}
\hline Gene name & Edit site location & Edit $\%$ TL-HC & STEDV, TL-HC & Edit \% TL-AD & STEDV, TL-AD & Edit \% difference (HC-AD) & $P$-value \\
\hline $\mathrm{CCNI}$ & chr4:77979680 & 32.263 & 9.467 & 25.467 & 5.618 & 6.796 & 0.043 \\
\hline FBXL6 & chr8:145579192 & 1.541 & 0.525 & 0.883 & 0.706 & 0.658 & 0.022 \\
\hline FLJ43663 & chr7:130629626 & 48.219 & 18.139 & 32.019 & 11.953 & 16.200 & 0.017 \\
\hline FLJ43663 & chr7:130629625 & 19.232 & 8.801 & 11.347 & 4.527 & 7.885 & 0.024 \\
\hline GRIA2 & chr4:158257879 & 16.858 & 3.167 & 13.138 & 3.485 & 3.720 & 0.015 \\
\hline GRIA2 & chr4:158257875 & 98.951 & 0.935 & 97.932 & 1.080 & 1.019 & 0.027 \\
\hline GRIA4 & chr11:105804694 & 62.881 & 17.217 & 46.408 & 11.297 & 16.473 & 0.011 \\
\hline GRIK1 & chr21:30953750 & 52.053 & 11.132 & 39.485 & 10.482 & 12.569 & 0.011 \\
\hline GRIK2 & chr6:102372572 & 13.892 & 3.802 & 10.862 & 3.167 & 3.030 & 0.049 \\
\hline MEG3 & chr14:101312647 & 58.903 & 11.226 & 48.246 & 6.575 & 10.657 & 0.009 \\
\hline MEG3 & chr14:101312645 & 9.952 & 2.588 & 7.398 & 1.791 & 2.554 & 0.011 \\
\hline MFN1 & chr3:179093025 & 5.004 & 2.189 & 2.066 & 1.350 & 2.938 & 0.001 \\
\hline MFN1 & chr3:179093028 & 10.983 & 5.102 & 5.358 & 3.233 & 5.625 & 0.004 \\
\hline MFN1 & chr3:179093014 & 15.313 & 7.498 & 6.239 & 3.715 & 9.074 & 0.004 \\
\hline MFN1 & chr3:179093021 & 6.453 & 3.014 & 3.083 & 1.365 & 3.370 & 0.007 \\
\hline MFN1 & chr3:179093034 & 2.194 & 1.300 & 1.205 & 0.614 & 0.989 & 0.046 \\
\hline NARF & chr17:80441088 & 35.515 & 9.469 & 53.491 & 13.751 & -17.975 & 0.002 \\
\hline TMEM63B & chr6:44120349 & 19.837 & 5.877 & 15.345 & 4.458 & 4.492 & 0.049 \\
\hline UNC80 & chr2:210835613 & 7.470 & 4.611 & 3.022 & 2.269 & 4.448 & 0.016 \\
\hline
\end{tabular}

of microfluidic PCR with deep sequencing output. It enables ultra-high coverage and accurate editing level measurement, while keeping the cost per sample rather low. Thus, it allows for accurate determination of editing levels along with the option to screen across tens of samples on a single run (Zhang et al. 2014). Here we present the first example of using this approach to screen for differences in A-to-I RNA editing between healthy and Alzheimer's disease samples. While clearly one cannot conclude that these differences contribute to $\mathrm{AD}$ development, these modifications may corroborate better understanding of the molecular mechanisms underlying the disease, and possibly be utilized as diagnostic markers. We found an overall down-regulation of RNA editing levels in Alzheimer's disease (AD) samples compared with sexand age-matched healthy nondemented controls (NDC), in all three brain regions screened, and observed site-specific differential editing in 35 sites that are located in 22 different genes. Interestingly, only three sites were found to have hypo- editing levels in $\mathrm{AD}$ that is shared by all three regions; the evolutionarily conserved edit site located in the UNC80 gene and the two adjacent sites located in the RNA gene MEG3. Notably, UNC80 is a component of the NALCN sodium channel complex, which regulates its ion conduction in both mammals and invertebrates. Animal models revealed an involvement in many processes such as locomotor behaviors, with mice lacking NALCN exhibited neonatal lethality due to respiratory rhythm defects (Lu et al. 2007; CochetBissuel et al. 2014). Furthermore, hypo-editing in $\mathrm{AD}$ was also seen in the noncoding RNA gene LINC-PINT (FLJ43663), which is crucial for proper brain development (Nie et al. 2012; Sauvageau et al. 2013; Guffanti et al. 2014). A strong decrease in editing was observed in the hippocampus (all three sites) and in the temporal lobe (two sites) but not in the frontal lobe. Finally, other eight editing sites also show hypo-editing in $\mathrm{AD}$ that is shared by two of the three brain regions tested (Table 6).

TABLE 3. Target sites with significant differential editing levels in frontal lobe of AD and NDC

\begin{tabular}{|c|c|c|c|c|c|c|c|}
\hline Gene & Edit site location & Edit \% FL-HC & STEDV, Edit \% FL-HC & Edit \% FL-AD & STEDV, Edit \% FL-AD & $\begin{array}{c}\text { Edit \% difference } \\
\text { (HC-AD) }\end{array}$ & $P$-value \\
\hline MFN1 & chr3:179093025 & 6.8627 & 3.1178 & 3.1747 & 2.1152 & 3.6881 & 0.0028 \\
\hline GRIK2 & chr6:102337689 & 28.3433 & 10.3811 & 16.3277 & 11.1951 & 12.0156 & 0.0156 \\
\hline MEG3 & chr14:101312647 & 54.6923 & 13.1138 & 43.9183 & 7.5353 & 10.7739 & 0.0214 \\
\hline MFN1 & chr3:179093021 & 7.9281 & 3.9253 & 4.7067 & 2.2747 & 3.2213 & 0.0218 \\
\hline GRIA2 & chr4:158257879 & 16.4785 & 2.6232 & 13.5295 & 3.3092 & 2.9490 & 0.0311 \\
\hline UNC80 & chr2:210835613 & 9.5859 & 4.9712 & 5.5987 & 3.7229 & 3.9873 & 0.0389 \\
\hline DDX58 & chr9:32456365 & 27.8542 & 10.2583 & 18.8311 & 10.2401 & 9.0231 & 0.0486 \\
\hline MEG3 & chr14:101312645 & 8.9579 & 2.7098 & 6.4071 & 1.3082 & 2.5508 & 0.0179 \\
\hline
\end{tabular}


TABLE 4. RNA editing levels recorded for the A, B, C, D prominent edit sites of HTR2C

\begin{tabular}{lcccccccrr}
\hline Edit site location & Gene & Edit \% TL-HC & SEM & Edit \% TL-AD & SEM & TL difference (HC-AD) & SEM & $P$-value & Edit by ADAR \\
\hline chrX:114082682 & HTR2C-A & 31.0690 & 6.294 & 23.4699 & 5.430 & 7.5991 & 0.746 & 0.409 & ADAR1 \\
chrX:114082684 & HTR2C-B & 19.5863 & 2.422 & 10.9634 & 2.140 & 8.6228 & 0.879 & 0.136 & ADAR1 \\
chrX:114082689 & HTR2C-C & 19.4558 & 5.071 & 14.0767 & 5.248 & 5.3792 & 0.426 & 0.339 & ADAR1+ ADAR2 \\
chrX:114082694 & HTR2C-D & 24.0464 & 4.235 & 19.1937 & 3.987 & 4.8527 & 0.655 & 0.548 & ADAR2 \\
\hline Edit site location & Gene & Edit \% FL-HC & SEM & Edit \% FL-AD & SEM & FL difference (HC-AD) & SEM & P-value & Edit by ADAR \\
\hline chrX:114082682 & HTR2C-A & 25.1052 & 3.890 & 16.2523 & 3.333 & 8.8529 & 0.422 & 0.307 & ADAR1 \\
chrX:114082684 & HTR2C-B & 15.4892 & 3.010 & 8.4339 & 2.875 & 7.0552 & 0.774 & 0.163 & ADAR1 \\
chrX:114082689 & HTR2C-C & 15.2670 & 3.112 & 10.2186 & 3.246 & 5.0484 & 0.655 & 0.319 & ADAR1+ ADAR2 \\
chrX:114082694 & HTR2C-D & 21.8976 & 6.068 & 12.3237 & 5.798 & 9.5738 & 1.045 & 0.190 & ADAR2 \\
\hline
\end{tabular}

This table describes the recorded RNA editing level per each editing site of HTR2C (sites A-D) as well as the calculated differential editing levels per each site in hippocampus, temporal lobe, and frontal lobe of NDC and AD. The table also shows the calculated $P$-value ( $t$-test) per each site as well as the editing ADAR responsible for the recoding of the site.

We found down-regulation of RNA editing in several glutamate receptors: GRIA2 (in TL and FL), GRIA4 (in TL and $\mathrm{HpC}$ ), and GRIA3 (in $\mathrm{HpC}$ ). It was already noticed that even mild deregulation of editing levels in these genes may contribute to the demising phenotype of $\mathrm{AD}$ (Gaisler-Salomon et al. 2014). The global hypo-editing pattern observed does not fully correlate with ADAR expression patterns, suggesting that more factors are involved. One should also bear in mind that due to motor neuron death, it is possible that the celltype composition is altered in $\mathrm{AD}$ samples, and thus it is possible that while editing level in each cell-type population is not changed in $\mathrm{AD}$, changes in the relative abundance of neurons and glia cells, for example, could have an effect on the global editing level measured. Future studies, using mi- cro-dissection and cell-specific editing quantification, might help to further elucidate this possibility.

\section{MATERIALS AND METHODS}

\section{Data and classification of brain samples cohorts}

Post-mortem samples were collected from three brain regions: hippocampus (HpC), temporal lobe (TL), and frontal lobe (FL) of Alzheimer's disease (AD) and nondemented controls (NDC). The samples were provided by the Netherlands Brain Bank (NBB), Brain and Tissue Bank for Developmental Disorders (NICHD), London Neurodegenerative Diseases Brain Bank (LNDBB), and Parkinson's UK Brain Bank (PUKBB). The AD and NDC samples are gender and age matched. The $\mathrm{AD}$ samples were all tested positive

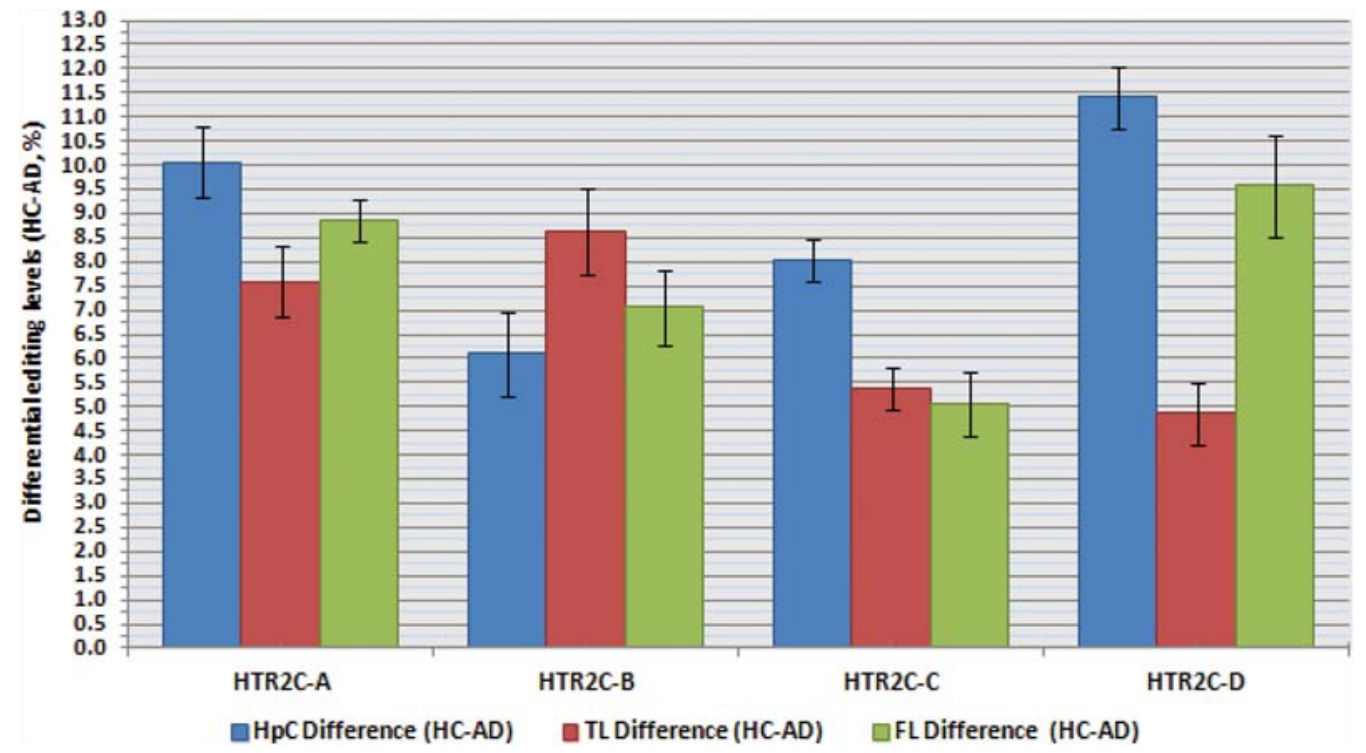

FIGURE 2. Differential levels of RNA editing between AD and NDC for the predominant sites of HTR2C. The results show hypo-editing of the four predominant sites of HTR2C (sites $A-D$ ) in AD compared with NDC in hippocampus (blue bars), temporal lobe (red bars), and frontal lobe (green bars). The graph points to a trend in the recorded editing levels, although none of these results were found to be statistically significant. Values are represented as mean \pm SEM. 
TABLE 5. The relative abundance (\%) of various HTR2C isoforms generated by different patterns of RNA editing

\begin{tabular}{|c|c|c|c|c|c|c|c|c|c|c|c|c|}
\hline \multirow[b]{2}{*}{$\begin{array}{l}\text { HTR2C-AA } \\
\text { sequence }\end{array}$} & \multirow[b]{2}{*}{$\begin{array}{l}\mathrm{NDC} \\
-\mathrm{HpC}\end{array}$} & \multicolumn{2}{|c|}{ Hippocampus } & \multirow[b]{2}{*}{$\begin{array}{l}\text { SD AD } \\
-\mathrm{HpC}\end{array}$} & \multirow[b]{2}{*}{$\begin{array}{c}\mathrm{NDC}- \\
\mathrm{TL}\end{array}$} & \multicolumn{2}{|c|}{ Temporal lobe } & \multirow{2}{*}{$\begin{array}{c}\mathrm{SD} \\
\mathrm{AD}- \\
\mathrm{TL}\end{array}$} & \multirow[b]{2}{*}{$\begin{array}{c}\mathrm{NDC}- \\
\mathrm{FL}\end{array}$} & \multicolumn{2}{|c|}{ Frontal lobe } & \multirow[b]{2}{*}{$\begin{array}{c}\text { SD } \\
\text { AD—FL }\end{array}$} \\
\hline & & $\begin{array}{c}\mathrm{SD} \\
\mathrm{NDC}-\mathrm{HpC}\end{array}$ & $\begin{array}{l}\mathrm{AD}- \\
\mathrm{HpC}\end{array}$ & & & $\begin{array}{l}\mathrm{NDC} \\
-\mathrm{TL}\end{array}$ & $\begin{array}{l}\mathrm{AD}- \\
\mathrm{TL}\end{array}$ & & & $\begin{array}{c}\mathrm{SD} \\
\mathrm{NDC}-\mathrm{FL}\end{array}$ & $\begin{array}{c}\mathrm{AD}- \\
\mathrm{FL}\end{array}$ & \\
\hline INI & 44.694 & 8.035 & 57.627 & 8.533 & 63.353 & 7.085 & 68.911 & 8.272 & 68.808 & 8.057 & 77.988 & 6.480 \\
\hline VSV & 4.015 & 0.820 & 2.541 & 0.898 & 8.760 & 1.736 & 6.763 & 2.234 & 8.287 & 2.413 & 4.226 & 1.767 \\
\hline VNV & 6.410 & 1.216 & 4.187 & 1.267 & 8.026 & 2.124 & 6.515 & 2.280 & 7.448 & 2.361 & 4.043 & 1.763 \\
\hline VNI & 5.628 & 1.060 & 3.889 & 1.140 & 4.012 & 0.964 & 5.721 & 1.597 & 3.814 & 1.037 & 3.346 & 1.174 \\
\hline VGV & 10.425 & 6.728 & 2.165 & 0.000 & 2.828 & 0.964 & 0.484 & 0.325 & 2.173 & 0.826 & 0.848 & 0.350 \\
\hline INV & 3.755 & 0.848 & 3.135 & 1.172 & 1.652 & 0.497 & 4.138 & 2.066 & 2.029 & 0.949 & 1.654 & 0.444 \\
\hline VSI & 8.663 & 1.728 & 5.417 & 1.624 & 1.840 & 0.584 & 0.983 & 0.371 & 1.621 & 0.638 & 1.495 & 0.619 \\
\hline VGI & 1.560 & 0.654 & 2.147 & 0.882 & 2.197 & 0.547 & 1.469 & 0.594 & 0.747 & 0.337 & 0.710 & 0.281 \\
\hline ISV & 1.858 & 0.585 & 1.435 & 0.537 & NA & NA & NA & NA & 1.108 & 0.456 & 0.903 & 0.382 \\
\hline ISI & 1.678 & 0.374 & 1.796 & 0.521 & 1.918 & 0.510 & 1.726 & 0.804 & 1.024 & 0.383 & 1.719 & 0.468 \\
\hline VDV & 14.180 & 5.299 & 1.172 & 0.490 & 1.803 & 0.891 & 0.513 & 0.346 & 0.513 & 0.287 & 0.377 & 0.208 \\
\hline VDI & 1.979 & 0.873 & 1.981 & 0.685 & 1.038 & 0.470 & 0.130 & 0.100 & 0.289 & 0.202 & 0.610 & 0.329 \\
\hline
\end{tabular}

for $\mathrm{AD}$ symptoms as denoted by the BRAAK score (Table 7; Supplemental Table S3; Braak and Braak 1991).

\section{RNA and cDNA preparation}

Total RNAs were extracted from frozen tissue samples of AD patients and gender- and age-matched nondemented controls obtained from different bio-banks (Supplemental Table S2) using the mirVana miRNA Isolation Kit (Ambion, Life Technologies), according to the procedure supplied by the manufacturers. Total RNA quality was analyzed on the BioAnalyzer 2100 (Agilent), obtaining RIN (RNA Integrity Number) values ranging from 5 to 8, considered acceptable for RNA derived from post-mortem tissues. Six $\mu$ g of total RNA were retro transcribed using the iScript Advanced cDNA Synthesis Kit for RT-qPCR (Bio-Rad Laboratories Ltd.). The cDNA was purified with MinElute PCR Purification Kit (Qiagen).

\section{Targeted resequencing of RNA editing sites in RNA samples using the Fluidigm Access Array coupled with the Ion-Torrent PGM}

To precisely detect and measure the levels of A-to-I RNA editing in healthy and diseased samples, targeted amplicons were generated and barcoded using a two-step PCR strategy which also minimized the total number of primers required. The target gene specific primers were designed using Primer 3.0 (http://frodo.wi.mit.edu/) to be located in exons while spanning introns, thus avoiding DNA contaminations to the RNA and by the 454 tool for designing of fusion primers supplemented with universal consensus sequences: [http://eu.idtdna.com/scitools/applications/fusionprimers/default .aspx.(IDT).] The primers were tested for specificity and sensitivity by PCR, before they were included in the primers set.

The Fluidigm Access Array is a high-throughput target-enrichment system designed to produce PCR products that could be compatible with all of the major next-generation sequencers. It enables us to create enriched multiple PCR products from 48 samples, all at once. Using the Access Array IFC, we can automatically assemble as little as 2304 PCR reactions, each reaction combining cDNA from one of the 48 samples and one of the 48 primer pairs. The FLDGM-AA amplification and tagging strategy is based on two consecutive PCR reactions, each done with specific fusion PCR primers. The first PCR is performed "on chip" and generates amplicons containing the editing target sites flanked by common universal sequences [CS1 (fused to the forward primer)/CS2 (fused to the reverse primer)]. The second PCR is performed "off chip" using a standard thermal cycler and make use of the first PCR's products as templates. The CS regions previously conjoined (by the previous PCR) enables the attachment of various barcodes to the amplicons, generating longer products. These longer amplicons contains not only the 10 bps sample specific barcode sequences, as well as the Ion-Torrent PGM tr-P1 \& A-seq adaptors. Thus, the final PCR output per each sample is a mini-library that is consisted of multiple sequences representing the 48 different target-specific primers pairs, whereas all of them are tagged with the same barcode sequence, which is representative of a single RNA sample. Accordingly, the unified library that is loaded for sequencing is comprised of all 48 mini-libraries represents the entire samples panel.

A schematic representation of the three major steps in the quantification of multiple RNA editing sites by next-generation sequencing (Supplemental Fig. S1): (Step 1) A microfluidics-based PCR using FAA platform generates targeted amplicons from up to 48 samples. Fluidigm Access Array IFC (chip) with samples and primers inlets marked by black arrows. Schematic representation of the "on-chip" PCR; target region (blue lines) that contain targeted RNA editing site (red circle) being amplified by PCR with forward and reverse target-specific primers (TSP-F/TSP-R) fused to common sequences (CS1/CS2). (Step 2) “Off chip" PCR that generates mini-library indexing tagging and the attachment addition of ITadaptor sequences to create fully tagged and sequencer compatible 48 mini-libraries. Completed amplicons (blue lines flanked by red lines) generated by "off chip" PCR using fusion primers containing CS1 and CS2 (red line of primers) and the Ion-Torrent PGM adaptor sequences P1 (green) and Aseq (orange). Barcode sequences (yellow) for sample indexing are fused to the Aseq-CS2 primer. (Step 3) Parallel sequencing of the combined library on IonTorrent PGM using the $1 \mathrm{G}-318$ chip. All 48 mini-libraries 
A

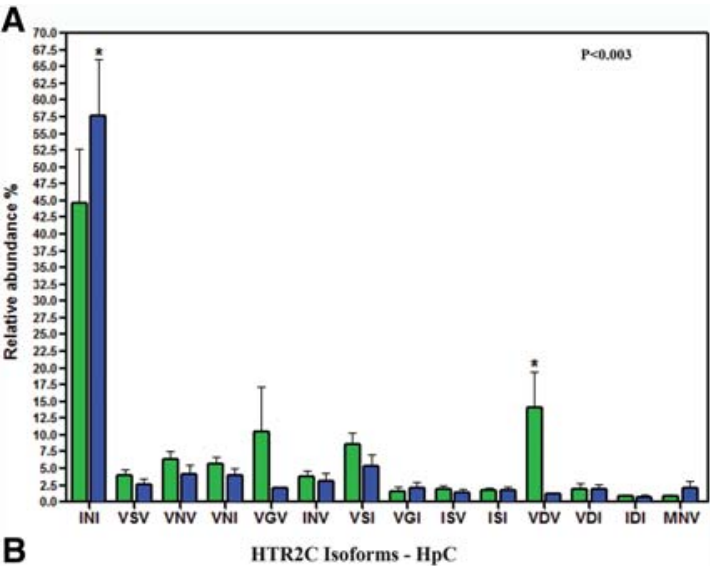

B

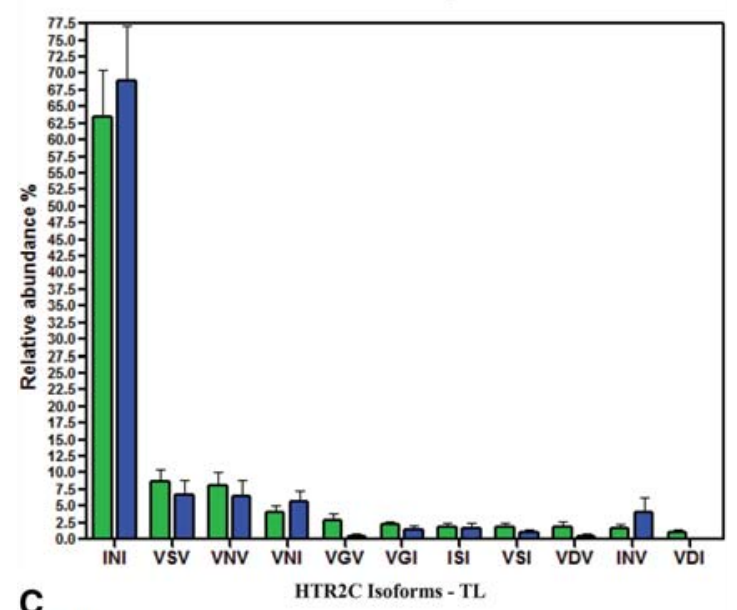

c

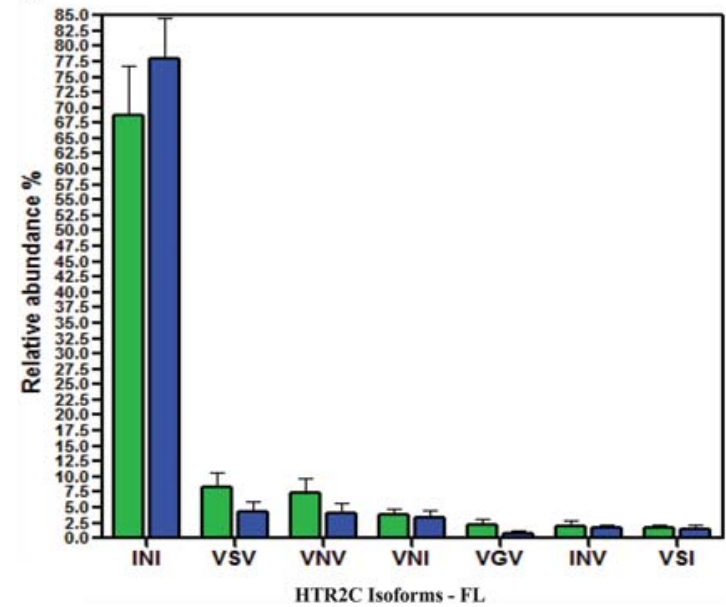

FIGURE 3. Relative abundance of HTR2C mRNA variants formed by RNA editing. The relative abundance of HTR2C mRNA variants formed by RNA editing detected in each brain region in $\mathrm{AD}$ (green bars) and NDC (blue bars). (A) Hippocampus data show a $13 \%$ increase from $45 \%$ in NDC to $58 \% \mathrm{AD}$ in the relative abundance of the unedited form INI (Ile157-Asn-159-Ile161). This rise is accompanied by a $12.5 \%$ decrease in the relative abundance of the edited form VDV detected in $\mathrm{AD}$. (B) Data from temporal lobe of $\mathrm{AD}$ (green bars) and NDC (blue bars) show no significant changes in their relative abundance between $\mathrm{AD}$ and NDC. $(C)$ Data from frontal lobe of $\mathrm{AD}$ (green bars) and NDC (blue bars) show no significant changes in their relative abundance between $\mathrm{AD}$ and NDC. (Values are represented as mean $\pm \mathrm{SD}$. [ $\left.{ }^{*}\right]$ $P<0.003$, two-way ANOVA). representing all 48 samples are constructed of full-length amplicons containing the targeted edit site, barcode sequence for sample identification and sequencer compatible adaptors are pooled together and analyzed on the Ion-Torrent PGM machine.

\section{Amplification of the target regions containing the target editing sites using the Fluidigm Access Array microfluidic system}

Four microliters of single primers pair $(4 \mu \mathrm{M}$ per primer in $1 \times \mathrm{AA}-$ loading buffer) were loaded into the primer inlets of the 48.48 Access Array IFC (Fluidigm). To prepare the cDNA templates, we added $2.25 \mu \mathrm{L}$ of each cDNA sample to $2.75 \mu \mathrm{L}$ of presample mix containing the following enzyme and reagents from the Roche FastStart High Fidelity PCR System; $0.5 \mu \mathrm{L}$ of $10 \times$ FastStart High Fidelity Reaction Buffer wo/Mg, $0.5 \mu \mathrm{L}$ DMSO (5\%), $0.1 \mu \mathrm{L} 10 \mathrm{mM}$ PCR Grade Nucleotide Mix $(200 \mu \mathrm{M}), 0.9$ $\mu \mathrm{L} 25 \mathrm{mM} \mathrm{MgCl} 2(4.5 \mathrm{Mm}), 0.25 \mu \mathrm{L} 20 \times$ Access Array Loading Reagent (Fluidigm), $0.05 \mu \mathrm{L}$ of FastStart High Fidelity Enzyme Blend and $0.7 \mu \mathrm{L}$ of PCR grade water. Four microliters of this mix was loaded into the samples inlets of the 48.48 Access Array IFC (Fluidigm). After the loading of both samples and primers via IFC Controller AX (Fluidigm) loading script, the IFC was subject to thermal cycling using FC1 Cycler (Fluidigm) with the following program for 40 cycles: $50^{\circ} \mathrm{C}$ for $2 \mathrm{~min}, 70^{\circ} \mathrm{C}$ for $20 \mathrm{~min}$, $95^{\circ} \mathrm{C} 10 \mathrm{~min} ; 10 \mathrm{cycles}$ of: $95^{\circ} \mathrm{C}$ for $15 \mathrm{sec}, 59.5^{\circ} \mathrm{C}$ for $30 \mathrm{sec}, 72^{\circ}$ $\mathrm{C}$ for $1 \mathrm{~min} ; 4$ cycles of: $95^{\circ} \mathrm{C}$ for $15 \mathrm{sec}, 80^{\circ} \mathrm{C}$ for $30 \mathrm{sec}, 59.5^{\circ} \mathrm{C}$ for $30 \mathrm{sec}, 72^{\circ} \mathrm{C}$ for $1 \mathrm{~min} ; 10$ cycles of: $95^{\circ} \mathrm{C}$ for $15 \mathrm{sec}, 59.5^{\circ} \mathrm{C}$ for $30 \mathrm{sec}, 72^{\circ} \mathrm{C}$ for $1 \mathrm{~min} ; 4$ cycles of: $95^{\circ} \mathrm{C}$ for $15 \mathrm{sec}, 80^{\circ} \mathrm{C}$ for $30 \mathrm{sec}, 60^{\circ} \mathrm{C}$ for $30 \mathrm{sec}, 72^{\circ} \mathrm{C}$ for $1 \mathrm{~min} ; 8$ cycles of: $95^{\circ} \mathrm{C}$ for 15 sec, $59.5^{\circ} \mathrm{C}$ for $30 \mathrm{sec}, 72^{\circ} \mathrm{C}$ for $1 \mathrm{~min} ; 4$ cycles of: $95^{\circ} \mathrm{C}$ for 15 sec, $80^{\circ} \mathrm{C}$ for $30 \mathrm{sec}, 60^{\circ} \mathrm{C}$ for $30 \mathrm{sec} ; 72^{\circ} \mathrm{C}$ for $1 \mathrm{~min}$; finalizing with $72^{\circ} \mathrm{C}$ for $3 \mathrm{~min}$. Once PCR has terminated, the IFC was transferred to another IFC Controller AX (Fluidigm) and mini-libraries were harvested by the controller harvest script.

\section{Sequencing adaptor and barcode addition}

For each sample, $1.0 \mu \mathrm{L}$ of the PCR products harvested from the IFC was 1:110 diluted and added to $15 \mu \mathrm{L}$ of presample mix containing the following enzyme and reagents from the Roche FastStart High Fidelity PCR System; $2 \mu \mathrm{L}$ of $10 \times$ FastStart High Fidelity Reaction Buffer wo/Mg, $1 \mu \mathrm{L}$ DMSO (5\%), $0.4 \mu \mathrm{L} 10 \mathrm{mM}$ PCR Grade Nucleotide Mix $(200 \mu \mathrm{M}), 3.6 \mu \mathrm{L} 25 \mathrm{mM} \mathrm{MgCl}_{2}(4.5 \mathrm{mM}), 0.2$ $\mu \mathrm{L}$ of FastStart High Fidelity Enzyme Blend and $7.8 \mu \mathrm{L}$ of PCR grade water. To that samples mix, $4 \mu \mathrm{L}$ of primer mix from the $2 \mu \mathrm{M}$ Access Array Barcode Library for Ion-Torrent PGM Sequencer96 (P/N100-4911), utilizing the B-set; A-BC-CS2 and P1-CS1 barcode primer combination. We used the following PCR program: $95^{\circ} \mathrm{C}$ for $10 \mathrm{~min} ; 10$ cycles of $95^{\circ} \mathrm{C}$ for $30 \mathrm{sec}, 60^{\circ} \mathrm{C}$ for $30 \mathrm{sec}$, and $72^{\circ} \mathrm{C}$ for $1 \mathrm{~min}$; and $72^{\circ} \mathrm{C}$ for $5 \mathrm{~min}$.

\section{Fluidigm library sequencing}

Libraries were pooled and sequenced on Ion-Torrent PGM using the Ion PGM Sequencing 200 Kit v2 and the 1G-Ion 318 Chip Kit v2 according to all manufacturer instructions (Life Technologies). 
A

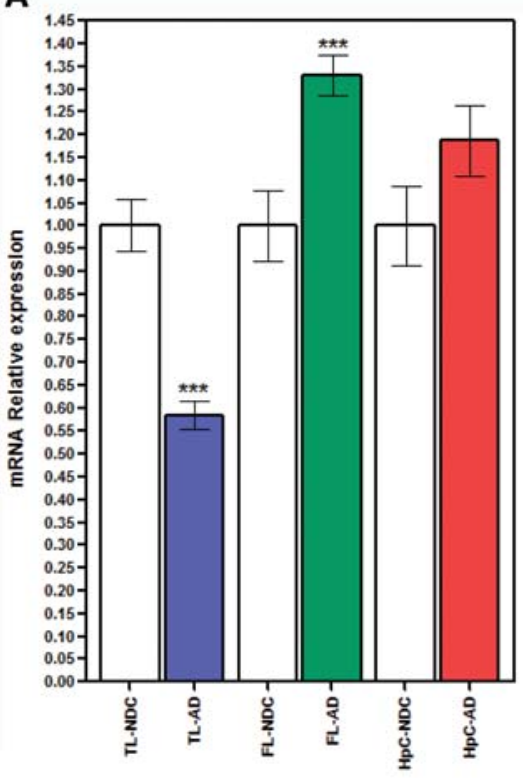

ADAR-p110
B

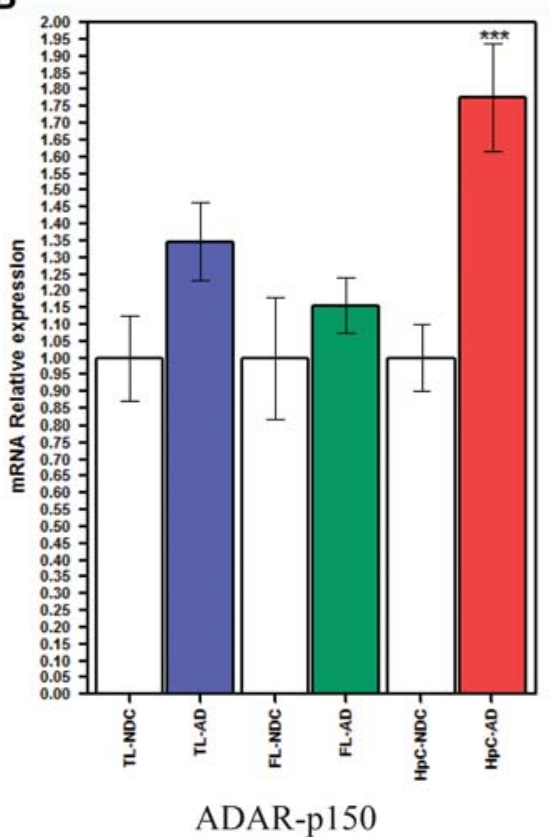

C

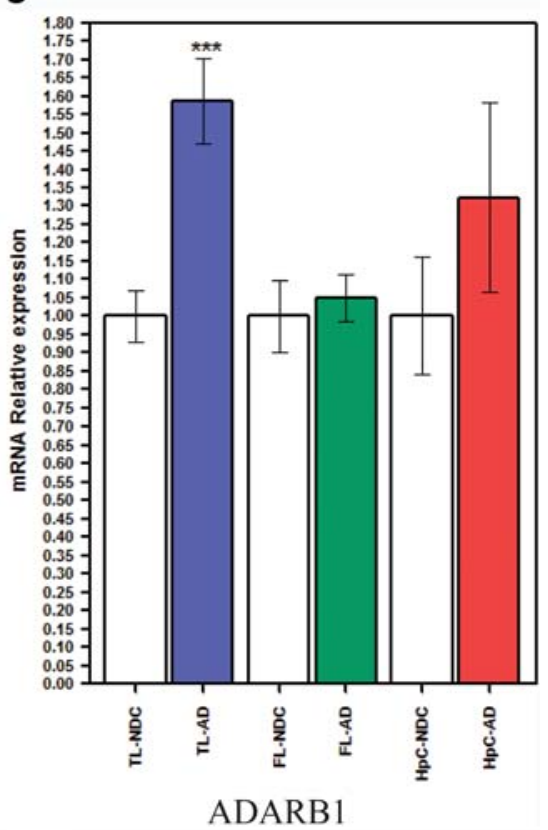

FIGURE 4. mRNA expression of hADAR1 and hADARB1 in hippocampus, temporal lobe, and frontal lobe of AD. Relative mRNA expression of the two human ADAR1 isoforms, hADAR1-p110 $(A)$ and hADAR1-p150 (B), and of hADARB1 $(C)$ was calculated for hippocampus (red bars), temporal lobe (blue bars), and frontal lobe (green bars) of AD and NDC (blank bars). (A) Transcription levels of endogenous hADAR1-p110 are down-regulated in the TL of $\mathrm{AD}$ (blue bars) and overexpressed in the $\mathrm{FL}$ of $\mathrm{AD}$ (green bars). No significant change was detected in the hippocampus. (B) Transcription levels of endogenous hADAR-p150 display an overexpression in hippocampus of AD (red bars) compared with their matched NDC (blank bars), while no significant change was detected in the TL or the FL. (C) Transcription levels of endogenous hADARB1 show an overexpression in TL of AD (blue bars) compared with their matched NDC (blank bars), while no significant change was detected in the FL or the HpC. Values are represented as means \pm SEM. ([***] $P<0.001$, MW test. $n=10$ in each group).

\section{Bioinformatic sequence analysis}

We used the UCSC genome browser Human Feb. 2009 (GRCh37/ hg19) assembly for identifying any discrepancies between the Refseq data to that obtained from the actual DNA sequencing output. For our focused screen, we have used a targeted-resequencing approach of NGS (next-generation sequencing) to generate and sequenced multiple PCR amplicons containing the target editing

TABLE 6. Shared differentially edited sites discovered in $\mathrm{HpC}$, TL, and $F L$ of $A D$

\begin{tabular}{lcrrr}
\hline \multicolumn{5}{c}{ \% Differential RNA editing levels (HC-AD) } \\
\hline Gene & Edit site location & HpC & \multicolumn{1}{c}{ TL } & \multicolumn{1}{c}{ FL } \\
\hline UNC80 & chr2:210835613 & 2.80 & 3.03 & 3.99 \\
MEG3 & chr14:101312645 & 3.76 & 3.72 & 2.55 \\
MEG3 & chr14:101312647 & 21.06 & 4.45 & 10.77 \\
GRIA4 & chr11:105804694 & 12.52 & 2.55 & \\
GRIK1 & chr21:30953750 & 8.07 & 12.57 & \\
FLJ43663 & chr7:130629626 & 14.48 & 5.63 & \\
FLJ43663 & chr7:130629625 & 11.99 & 9.07 & \\
GRIA2 & chr4:158257879 & & 3.37 & 2.95 \\
GRIK2 & chr6:102372572 & & 16.47 & 12.02 \\
MFN1 & chr3:179093025 & & 16.20 & 3.69 \\
MFN1 & chr3:179093021 & & 1.02 & 3.22 \\
\hline
\end{tabular}

site/s. The analysis of data obtained was performed to detect any A/G mismatches within the cDNA sequences. Such mismatches were summed and scored for their signal strength according to the overall number of coverage reads and more important to the percentage of A-to-G levels.

\section{Pre-alignment processing}

The sequencing data were downloaded from the machine as fastq file. First, all raw sequences data were de-indexed into 48 samples according to the barcodes used by an in-house script. All reads were trimmed of the universal CS1 and CS2 sequences and all short reads ( $<20 \mathrm{nts}$ ) were removed. Alignment of the processed reads was made using bwa version 0.7.4-r385, using the mem option and the parameters: - $\mathrm{k} 20$-B 3 -O 3 - T 20, for seed in the length of the average primer, and for considering the Ion typical error of small indels.

\section{Alignments process}

The alignment was done to the human refseq database, where reads that were aligned to more than one location were omitted from further analysis. We used samtools mpileup on the alignment results and run in-house script to move the results to the genomic locations from the refseqs and then an in-house script to count the number of different nucleotides in each genomic location that had a $q$-score $\geq 20$. The last stage was to filter the results to a preset set of locations 
TABLE 7. Characterization of the samples cohorts, by brain region and diagnostic status

\begin{tabular}{lllccccc}
\hline Brain region & Diagnosis & Gender & No. of samples & Avg. age & SEM age & Avg. BRAAK AD & SEM BRAAK \\
\hline Frontal lobe (BA21) & AD & M & 13 & 75.07 & 1.04 & 5 & 0.148 \\
Temporal lobe (BA46) & AD & M & 13 & 75.07 & 1.04 & 5 & 0.148 \\
Hippocampus & AD & M & 28 & 75.51 & 0.67 & 5.52 & 0.114 \\
\hline Brain region & Diagnosis & Gender & No. of samples & Avg. age & SEM age & Avg. BRAAK NDC & SEM BRAAK \\
\hline Frontal lobe (BA21) & NDC & M & 11 & 73.77 & 1.23 & 0.352 & 0.135 \\
Temporal lobe (BA46) & NDC & M & 11 & 73.77 & 1.23 & 0.135 \\
Hippocampus & NDC & M & 20 & 75.15 & 1.45 & 0.234 & 0.121 \\
\hline
\end{tabular}

of interest, for each location we present the total number of reads which had good quality per each sample, and the calculated percentage of reads that have a "G" at the specified genomic location, was done accordingly with the formula; (\# of "G" reads / [\# of "G" reads + \# of "A" reads]).

\section{Real-time PCR quantification assays}

Relative mRNA quantification of ADAR-p110 and -p150 variants in addition to ADARB1 was determined using qRT-PCR. Total RNA was extracted and retro transcribed as detailed. For each tested variant, a total of nine biological samples were used. Relative transcript levels were determined by the 7900HT Fast Real-Time PCR System (Applied Biosystems). Triplicates of each cDNA sample were PCR-amplified using the PerfeCTa SYBR Green FastMix (Quanta BioSciences) and the following specific primers:

\section{ADAR-p110: 5'-GGCAGCCTCCGGGTG-3' and 5'-CTGTCTGTG CTCATAGCCTTG-3' \\ ADAR-p150: 5'-CGGGCAATGCCTCGC- ${ }^{\prime}$ and $5^{\prime}$-AATGGATGG GTGTAGTATCCGC-3' \\ ADARB1: 5'-CCGCAGGTTTTAGCTGACG-3' and 5'-CGGTCA GGTCACCAAACTTACC-3'}

The relative quantification of gene expression levels, was measured by the $\Delta \Delta \mathrm{C}_{\mathrm{T}}$ method (Schmittgen and Livak 2008) and normalized against the SDHA gene (NM_004168.3) using the following gene specific primers; 5'-TTTGATGCAGTGGTGGTAGG-3' and 5'TCACGGTGTCGTAGAAATGC- $3^{\prime}$. The selection of SDHA for normalization was based on several studies in which it was repeatedly found to be a stable housekeeping gene across various studies, among which included studies that involved AD samples (Eisenberg and Levanon 2013; Jacob et al. 2013; Leidinger et al. 2013; Park et al. 2013). In quantitative real-time PCR assay, gene levels normalizations factors were evaluated by dividing the absolute levels of SDHA gene in each sample by the average value over all NDC samples.

\section{Statistical analysis}

Two-way analysis of variance (ANOVA) was used to compare the expression levels in the $\mathrm{AD}$ samples. Editing levels were roughly normally distributed, and no normalization was applied. A $t$-test was used to compare, for each RNA editing site, between editing levels recorded in $\mathrm{AD}$ brain samples and brains of nondemented, age and gender matched, healthy controls (NDC). Benjamini-Hochberg multiple testing correction was used with $\mathrm{FDR}=0.1$. Throughout the paper, values are usually presented as means \pm standard error of the mean (SEM).

\section{SUPPLEMENTAL MATERIAL}

Supplemental material is available for this article.

\section{ACKNOWLEDGMENTS}

The authors thank Gideon Rechavi, Jin Billy Li, Rui Zhang, Gokul Ramaswami, and Itzhak Haviv for their assistance with the experimental system. We also thank Italia Aiello and Francesca Mastropasqua for support with brain tissues and Graziano Pesole for helpful suggestions. A special thanks is addressed to the following brain banks: Netherlands Brain Bank (NBB), Brain and Tissue Bank for Developmental Disorders (NICHD), London Neurodegenerative Diseases Brain Bank (LNDBB), and Parkinson's UK Brain Bank (PUKBB) for providing all tissues used in this study. This research was supported by a grant from the Ministry of Science, Technology and Space, Israel and the Ministry of Foreign Affairs, Italy to E.E. and E.P. Additional support came from the European Research Council (grant no. 311257), the I-CORE Program of the Planning and Budgeting Committee, and the Israel Science Foundation (grant nos. $41 / 11$ and $1796 / 12 ; 1380 / 14$ [E.Y.L.] and 379/12 [E.E.]). Additional support for E.Y.L. was provided by the Ministry of Science and Technology, Israel and the Japan Science and Technology Agency (JST), Japan (grant no.10765-3).

Received October 7, 2015; accepted November 18, 2015.

\section{REFERENCES}

Alzheimer's Association. 2014. 2014 Alzheimer's disease facts and figures includes a special report on women and Alzheimer's disease. Alzheimers Dement 10: e47-e92.

Athanasiadis A, Rich A, Maas S. 2004. Widespread A-to-I RNA editing of Alu-containing mRNAs in the human transcriptome. PLoS Biol 2: e391.

Bahn JH, Lee J-H, Li G, Greer C, Peng G, Xiao X. 2012. Accurate identification of A-to-I RNA editing in human by transcriptome sequencing. Genome Res 22: 142-150.

Barak M, Levanon EY, Eisenberg E, Paz N, Rechavi G, Church GM, Mehr R. 2009. Evidence for large diversity in the human transcriptome created by Alu RNA editing. Nucleic Acids Res 37: 6905-6915. 
Bass BL. 2002. RNA editing by adenosine deaminases that act on RNA. Annu Rev Biochem 71: 817-846.

Bazak L, Haviv A, Barak M, Jacob-Hirsch J, Deng P, Zhang R, Isaacs FJ, Rechavi G, Li JB, Eisenberg E, et al. 2014a. A-to-I RNA editing occurs at over a hundred million genomic sites, located in a majority of human genes. Genome Res 24: 365-376.

Bazak L, Levanon EY, Eisenberg E. 2014b. Genome-wide analysis of Alu editability. Nucleic Acids Res 42: 6876-6884.

Berg KA, Cropper JD, Niswender CM, Sanders-Bush E, Emeson RB, Clarke WP. 2001. RNA-editing of the 5- $\mathrm{HT}_{2 \mathrm{C}}$ receptor alters agonist-receptor-effector coupling specificity. Br J Pharmacol 134: 386-392.

Bhalla T, Rosenthal JJ, Holmgren M, Reenan R. 2004. Control of human potassium channel inactivation by editing of a small mRNA hairpin. Nat Struct Mol Biol 11: 950-956.

Blow M, Futreal PA, Wooster R, Stratton MR. 2004. A survey of RNA editing in human brain. Genome Res 14: 2379-2387.

Braak H, Braak E. 1991. Neuropathological stageing of Alzheimer-related changes. Acta Neuropathol 82: 239-259.

Burns CM, Chu H, Rueter SM, Hutchinson LK, Canton H, SandersBush E, Emeson RB. 1997. Regulation of serotonin-2C receptor G-protein coupling by RNA editing. Nature 387: 303-308.

Cenci C, Barzotti R, Galeano F, Corbelli S, Rota R, Massimi L, Di Rocco C, O'Connell MA, Gallo A. 2008. Down-regulation of RNA editing in pediatric astrocytomas: ADAR2 editing activity inhibits cell migration and proliferation. J Biol Chem 283: 7251-7260.

Chen LL, Carmichael GG. 2009. Altered nuclear retention of mRNAs containing inverted repeats in human embryonic stem cells: functional role of a nuclear noncoding RNA. Mol Cell 35: 467-478.

Chen CX, Cho DS, Wang Q, Lai F, Carter KC, Nishikura K. 2000. A third member of the RNA-specific adenosine deaminase gene family, ADAR3, contains both single- and double-stranded RNA binding domains. RNA 6: 755-767.

Cochet-Bissuel M, Lory P, Monteil A. 2014. The sodium leak channel, NALCN, in health and disease. Front Cell Neurosci 8: 132.

Eisenberg E, Levanon EY. 2013. Human housekeeping genes, revisited. Trends Genet 29: 569-574.

Feldmeyer D, Kask K, Brusa R, Kornau HC, Kolhekar R, Rozov A, Burnashev N, Jensen V, Hvalby O, Sprengel R, et al. 1999. Neurological dysfunctions in mice expressing different levels of the Q/R site-unedited AMPAR subunit GluR-B. Nat Neurosci 2: 57-64.

Gaisler-Salomon I, Kravitz E, Feiler Y, Safran M, Biegon A, Amariglio N, Rechavi G. 2014. Hippocampus-specific deficiency in RNA editing of GluA2 in Alzheimer's disease. Neurobiol Aging 35: $1785-1791$.

Garncarz W, Tariq A, Handl C, Pusch O, Jantsch MF. 2013. A highthroughput screen to identify enhancers of ADAR-mediated RNAediting. RNA Biol 10: 192-204.

Guffanti G, Gaudi S, Fallon JH, Sobell J, Potkin SG, Pato C, Macciardi F. 2014. Transposable elements and psychiatric disorders. Am J Med Genet B Neuropsychiatr Genet 165B: 201-216.

Hoopengardner B, Bhalla T, Staber C, Reenan R. 2003. Nervous system targets of RNA editing identified by comparative genomics. Science 301: 832-836.

Horsch M, Seeburg PH, Adler T, Aguilar-Pimentel JA, Becker L, Calzada-Wack J, Garrett L, Götz A, Hans W, Higuchi M, et al. 2011. Requirement of the RNA-editing enzyme ADAR2 for normal physiology in mice. J Biol Chem 286: 18614-18622.

Hundley HA, Krauchuk AA, Bass BL. 2008. C. elegans and H. sapiens mRNAs with edited $3^{\prime}$ UTRs are present on polysomes. RNA 14: 2050-2060.

Iwamoto K, Kato T. 2003. RNA editing of serotonin 2C receptor in human postmortem brains of major mental disorders. Neurosci Lett 346: $169-172$.

Iwamoto K, Nakatani N, Bundo M, Yoshikawa T, Kato T. 2005. Altered RNA editing of serotonin $2 \mathrm{C}$ receptor in a rat model of depression. Neurosci Res 53: 69-76.
Iwamoto K, Bundo M, Kato T. 2009. Serotonin receptor 2C and mental disorders: genetic, expression and RNA editing studies. RNA Biol 6: $248-253$.

Jacob F, Guertler R, Naim S, Nixdorf S, Fedier A, Hacker NF, Heinzelmann-Schwarz V. 2013. Careful selection of reference genes is required for reliable performance of RT-qPCR in human normal and cancer cell lines. PLoS One 8: e59180.

Jacobs MM, Fogg RL, Emeson RB, Stanwood GD. 2009. ADAR1 and ADAR2 expression and editing activity during forebrain development. Dev Neurosci 31: 223-237.

Johnson JM, Castle J, Garrett-Engele P, Kan Z, Loerch PM, Armour CD, Santos R, Schadt EE, Stoughton R, Shoemaker DD. 2003. Genomewide survey of human alternative pre-mRNA splicing with exon junction microarrays. Science 302: 2141-2144.

Kawahara Y, Sun H, Ito K, Hideyama T, Aoki M, Sobue G, Tsuji S, Kwak S. 2006. Underediting of GluR2 mRNA, a neuronal death inducing molecular change in sporadic ALS, does not occur in motor neurons in ALS1 or SBMA. Neurosci Res 54: 11-14.

Kawahara Y, Grimberg A, Teegarden S, Mombereau C, Liu S, Bale TL, Blendy JA, Nishikura K. 2008. Dysregulated editing of serotonin 2C receptor mRNAs results in energy dissipation and loss of fat mass. J Neurosci 28: 12834-12844.

Kim DD, Kim TT, Walsh T, Kobayashi Y, Matise TC, Buyske S, Gabriel A. 2004. Widespread RNA editing of embedded Alu elements in the human transcriptome. Genome Res 14: 1719-1725.

Kortenbruck G, Berger E, Speckmann EJ, Musshoff U. 2001. RNA editing at the $\mathrm{Q} / \mathrm{R}$ site for the glutamate receptor subunits GLUR2, GLUR5, and GLUR6 in hippocampus and temporal cortex from epileptic patients. Neurobiol Dis 8: 459-468.

Kwak S, Nishimoto Y, Yamashita T. 2008. Newly identified ADAR-mediated A-to-I editing positions as a tool for ALS research. RNA Biol 5: 193-197.

Lehmann KA, Bass BL. 2000. Double-stranded RNA adenosine deaminases ADAR1 and ADAR2 have overlapping specificities. Biochemistry 39: $12875-12884$.

Leidinger P, Backes C, Deutscher S, Schmitt K, Mueller SC, Frese K, Haas J, Ruprecht K, Paul F, Stähler C, et al. 2013. A blood based 12-miRNA signature of Alzheimer disease patients. Genome Biol 14: R78.

Levanon EY, Eisenberg E, Yelin R, Nemzer S, Hallegger M, Shemesh R, Fligelman ZY, Shoshan A, Pollock SR, Sztybel D, et al. 2004. Systematic identification of abundant A-to-I editing sites in the human transcriptome. Nat Biotechnol 22: 1001-1005.

Li JB, Church GM. 2013. Deciphering the functions and regulation of brain-enriched A-to-I RNA editing. Nat Neurosci 16: 1518-1522.

Li JB, Levanon EY, Yoon J-K, Aach J, Xie B, LeProust E, Zhang K, Gao Y, Church GM. 2009. Genome-wide identification of human RNA editing sites by parallel DNA capturing and sequencing. Science 324: $1210-1213$.

Li Z, Bammann H, Li M, Liang H, Yan Z, Phoebe Chen YP, Zhao M, Khaitovich P. 2013. Evolutionary and ontogenetic changes in RNA editing in human, chimpanzee, and macaque brains. RNA 19: $1693-1702$.

Li X, Overton IM, Baines RA, Keegan LP, O’Connell MA. 2014. The ADAR RNA editing enzyme controls neuronal excitability in Drosophila melanogaster. Nucleic Acids Res 42: 1139-1151.

Lu B, Su Y, Das S, Liu J, Xia J, Ren D. 2007. The neuronal channel NALCN contributes resting sodium permeability and is required for normal respiratory rhythm. Cell 129: 371-383.

Maas S, Patt S, Schrey M, Rich A. 2001. Underediting of glutamate receptor GluR-B mRNA in malignant gliomas. Proc Natl Acad Sci 98: $14687-14692$.

Maas S, Kawahara Y, Tamburro KM, Nishikura K. 2006. A-to-I RNA editing and human disease. RNA Biol 3: 1-9.

Melcher T, Maas S, Herb A, Sprengel R, Seeburg PH, Higuchi M. 1996. A mammalian RNA editing enzyme. Nature 379: 460-464.

Morabito MV, Ulbricht RJ, O'Neil RT, Airey DC, Lu P, Zhang B, Wang L, Emeson RB. 2010. High-throughput multiplexed transcript analysis yields enhanced resolution of 5-hydroxytryptamine $2 \mathrm{C}$ receptor mRNA editing profiles. Mol Pharmacol 77: 895-902. 
Nie L, Wu H, Hsu J, Chang S, Labaff AM, Li C, Wang Y. 2012. Long noncoding RNAs: versatile master regulators of gene expression and crucial players in cancer. Am J Transl Res 4: 127-150.

Nishikura K. 2010. Functions and regulation of RNA editing by ADAR deaminases. Annu Rev Biochem 79: 321-349.

Niswender CM, Copeland SC, Herrick-Davis K, Emeson RB, SandersBush E. 1999. RNA editing of the human serotonin 5-hydroxytryptamine 2C receptor silences constitutive activity. J Biol Chem 274: 9472-9478.

Niswender CM, Herrick-Davis K, Dilley GE, Meltzer HY, Overholser JC, Stockmeier CA, Emeson RB, Sanders-Bush E. 2001. RNA editing of the human serotonin 5-HT2C receptor. Alterations in suicide and implications for serotonergic pharmacotherapy. Neuropsychopharmacology 24: 478-491.

Park E, Williams B, Wold BJ, Mortazavi A. 2012. RNA editing in the human ENCODE RNA-seq data. Genome Res 22: 1626-1633.

Park S-J, Kim Y-H, Lee Y, Kim K-M, Kim H-S, Lee S-R, Kim S-U, Kim S-H, Kim J-S, Jeong K-J, et al. 2013. Selection of appropriate reference genes for RT-qPCR analysis in a streptozotocin-induced Alzheimer's disease model of cynomolgus monkeys (Macaca fascicularis). PLoS One 8: e56034.

Patterson JB, Samuel CE. 1995. Expression and regulation by interferon of a double-stranded-RNA-specific adenosine deaminase from human cells: evidence for two forms of the deaminase. Mol Cell Biol 15: 5376-5388.

Paz N, Levanon EY, Amariglio N, Spring C, Heimberger AB, Ram Z, Constantini S, Barbash ZS, Adamsky K, Safran M, et al. 2007. Altered adenosine-to-inosine RNA editing in human cancer. Genome Res 17: 1586-1595.

Paz-Yaacov N, Bazak L, Buchumenski I, Porath HT, DananGotthold M, Knisbacher BA, Eisenberg E, Levanon EY. 2015. Elevated RNA editing activity is a major contributor to transcriptomic diversity in tumors. Cell Rep 13: 267-276.

Peng Z, Cheng Y, Tan BC-M, Kang L, Tian Z, Zhu Y, Zhang W, Liang Y, Hu X, Tan X, et al. 2012. Comprehensive analysis of RNA-seq data reveals extensive RNA editing in a human transcriptome. Nat Biotechnol 30: 253-260.

Picardi E, Gallo A, Galeano F, Tomaselli S, Pesole G. 2012. A novel computational strategy to identify A-to-I RNA editing sites by RNA-seq data: de novo detection in human spinal cord tissue. PLoS One 7: e44184.

Pinto Y, Cohen HY, Levanon EY. 2014. Mammalian conserved ADAR targets comprise only a small fragment of the human editosome. Genome Biol 15: R5.

Prasanth KV, Prasanth SG, Xuan Z, Hearn S, Freier SM, Bennett CF, Zhang MQ, Spector DL. 2005. Regulating gene expression through RNA nuclear retention. Cell 123: 249-263.

Ramaswami G, Li JB. 2014. RADAR: a rigorously annotated database of A-to-I RNA editing. Nucleic Acids Res 42: D109-D113.

Ramaswami G, Lin W, Piskol R, Tan MH, Davis C, Li JB. 2012. Accurate identification of human $A l u$ and non-Alu RNA editing sites. Nat Methods 9: 579-581.

Ramaswami G, Zhang R, Piskol R, Keegan LP, Deng P, O'Connell MA, Li JB. 2013. Identifying RNA editing sites using RNA sequencing data alone. Nat Methods 10: 128-132.

Ray M, Zhang W. 2010. Analysis of Alzheimer's disease severity across brain regions by topological analysis of gene co-expression networks. BMC Syst Biol 4: 136.
Sanjana NE, Levanon EY, Hueske EA, Ambrose JM, Li JB. 2012. Activity-dependent A-to-I RNA editing in rat cortical neurons. Genetics 192: 281-287.

Sauvageau M, Goff LA, Lodato S, Bonev B, Groff AF, Gerhardinger C, Sanchez-Gomez DB, Hacisuleyman E, Li E, Spence M, et al. 2013. Multiple knockout mouse models reveal lincRNAs are required for life and brain development. Elife 2: e01749.

Savva YA, Rieder LE, Reenan RA. 2012. The ADAR protein family. Genome Biol 13: 252.

Scadden ADJ. 2005. The RISC subunit Tudor-SN binds to hyper-edited double-stranded RNA and promotes its cleavage. Nat Struct Mol Biol 12: 489-496.

Scadden ADJ. 2007. Inosine-containing dsRNA binds a stress-granulelike complex and downregulates gene expression in trans. Mol Cell 28: 491-500.

Schellekens H, Clarke G, Jeffery IB, Dinan TG, Cryan JF. 2012. Dynamic $5-\mathrm{HT}_{2 \mathrm{c}}$ receptor editing in a mouse model of obesity. PLoS One 7: $1-12$.

Schmittgen TD, Livak KJ. 2008. Analyzing real-time PCR data by the comparative C(T) method. Nat Protoc 3: 1101-1108.

Serrano-Pozo A, Frosch MP, Masliah E, Hyman BT. 2011. Neuropathological alterations in Alzheimer disease. Cold Spring Harb Perspect Med 1: 1-23.

Slotkin W, Nishikura K. 2013. Adenosine-to-inosine RNA editing and human disease. Genome Med 5: 105.

Sommer B, Koöhler M, Sprengel R, Seeburg PH. 1991. RNA editing in brain controls a determinant of ion flow in glutamate-gated channels. Cell 67: 11-19.

Sultan M, Schulz MH, Richard H, Magen A, Klingenhoff A, Scherf M, Seifert M, Borodina T, Soldatov A, Parkhomchuk D, et al. 2008. A global view of gene activity and alternative splicing by deep sequencing of the human transcriptome. Science 321: 956-960.

Tariq A, Jantsch MF. 2012. Transcript diversification in the nervous system: A to I RNA editing in CNS function and disease development. Front Neurosci 6: 99.

Tomaselli S, Locatelli F, Gallo A. 2014. The RNA editing enzymes ADARs: mechanism of action and human disease. Cell Tissue Res 356: 527-532.

Vissel B, Royle GA, Christie BR, Schiffer HH, Ghetti A, Tritto T, PerezOtano I, Radcliffe RA, Seamans J, Sejnowski T, et al. 2001. The role of RNA editing of kainate receptors in synaptic plasticity and seizures. Neuron 29: 217-227.

Vollmar W, Gloger J, Berger E, Kortenbruck G, Köhling R, Speckmann EJ, Musshoff U. 2004. RNA editing (R/G site) and flip-flop splicing of the AMPA receptor subunit GluR2 in nervous tissue of epilepsy patients. Neurobiol Dis 15: 371-379.

Wahlstedt H, Daniel C, Ensterö M, Ohman M. 2009. Large-scale mRNA sequencing determines global regulation of RNA editing during brain development. Genome Res 19: 978-986.

Wang Q, O’Brien PJ, Chen CX, Cho DS, Murray JM, Nishikura K. 2000. Altered G protein-coupling functions of RNA editing isoform and splicing variant serotonin ${ }_{2 C}$ receptors. J Neurochem 74: 12901300.

Zhang R, Li X, Ramaswami G, Smith KS, Turecki G, Montgomery SB, Li JB. 2014. Quantifying RNA allelic ratios by microfluidic multiplex PCR and sequencing. Nat Methods 11: 51-54. 

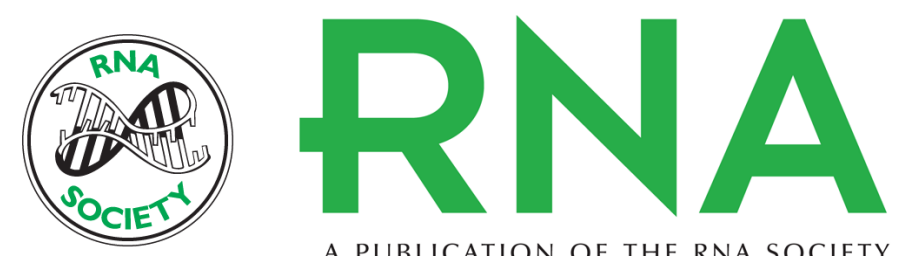

A PUBLICATION OF THE RNA SOCIETY

\section{Reduced levels of protein recoding by A-to-I RNA editing in Alzheimer's disease}

Khen Khermesh, Anna Maria D'Erchia, Michal Barak, et al.

RNA 2016 22: 290-302 originally published online December 11, 2015

Access the most recent version at doi:10.1261/rna.054627.115

\section{Supplemental http://rnajournal.cshlp.org/content/suppl/2015/11/30/rna.054627.115.DC1 \\ Material}

References This article cites 82 articles, 22 of which can be accessed free at: http://rnajournal.cshlp.org/content/22/2/290.full.html\#ref-list-1

Open Access Freely available online through the RNA Open Access option.

Creative This article, published in $R N A$, is available under a Creative Commons License Commons (Attribution 4.0 International), as described at

License http://creativecommons.org/licenses/by/4.0/.

Email Alerting Receive free email alerts when new articles cite this article - sign up in the box at the Service top right corner of the article or click here.

\section{|||||||| Providing Precise Solutions for your research.}

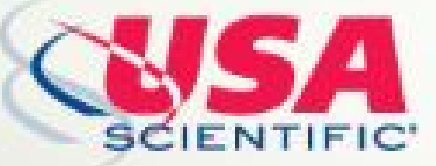

To subscribe to $R N A$ go to:

http://rnajournal.cshlp.org/subscriptions

(c) 2016 Khermesh et al.; Published by Cold Spring Harbor Laboratory Press for the RNA Society 